\title{
Biotransformation potential of hexavalent chromium by Bacillus pumilus-S4, Pseudomonas doudoroffii-S5 and Exiguobacterium-S8 in association with hydrophytes
}

\author{
S. Ejaz $\cdot$ F. Z. Rizvi $\cdot$ S. Anwar $\cdot$ M. Faisal
}

Received: 28 July 2011/Revised: 3 October 2011/Accepted: 9 January 2012/Published online: 20 March 2013

(C) Islamic Azad University (IAU) 2013

\begin{abstract}
Three chromium-resistant bacteria Bacillus pumilus-S4, Pseudomonas doudoroffii-S5 and Exiguobacterium-S8 were isolated from chromium-contaminated wastewater/soil and could resist very high concentrations of potassium chromate in Luria agar (up to $25 \mathrm{mg} \mathrm{ml}^{-1}$ ) and acetate minimal medium $\left(2 \mathrm{mg} \mathrm{ml}^{-1}\right)$. The strains showed growth at diverse $\mathrm{pH}$ and temperatures and could resist multiple heavy metals. Pseudomonas doudoroffii-S5 reduced $\left(8.27 \mathrm{mg}\right.$ hexavalent chromium $24 \mathrm{~h}^{-1}$ ) at a lower initial potassium chromate concentration $\left(100 \mu \mathrm{g} \mathrm{ml}^{-1}\right)$, but overall more chromate $(28.4 \mathrm{mg}$ hexavalent chromium $24 \mathrm{~h}^{-1}$ ) was reduced at a higher initial concentration $\left(1,000 \mu \mathrm{g} \mathrm{ml}^{-1}\right)$. The addition of various heavy metals (zinc sulphate, copper sulphate, and manganese sulphate at $50 \mu \mathrm{g} \mathrm{m}^{-1}$ ) in the chromium reduction media did not significantly affect the hexavalent chromium reduction potential of these isolates. The chromium removal/detoxification potential of these strains increased when used in conjunction with hydrophytes Eichornia crassipes and Pistia stratiotes. Interestingly, the whole process runs automatically with less energy input, that is, the bacterial strains support the
\end{abstract}

S. Ejaz · F. Z. Rizvi · S. Anwar · M. Faisal ( $₫)$ Department of Microbiology and Molecular Genetics, University of the Punjab, Quaid-e-Azam Campus, Lahore 54590, Pakistan

e-mail: mohdfaysal@yahoo.com growth of plant while in turn the plant releases exudates that help bacterial growth.

Keywords Bioremediation - Eichornia crassipes . Heavy metals · Pistia stratiotes

\section{Introduction}

Chromium compounds have widespread industrial uses in steel production, wood preservation, leather tanning, metal corrosion inhibition, paints and pigments, metal plating, and other applications (Swarnalatha et al. 2009). Chromium can exist in oxidation states ranging from +2 to +6 , but is most frequently found in the environment in the trivalent $(+3)$ and hexavalent $(+6)$ states (Parmar et al. 2010). Hexavalent (VI) is about 100-fold more toxic, mutagenic and well-known carcinogen than the trivalent (III) form (Kerger et al. 2009). Conventional methods for removing toxic $\mathrm{CrO}_{4}{ }^{2-}$ from wastewater include chemical reduction followed by precipitation, ion exchange, and adsorption on activated coal, alum, kaolinite, and ash (Camargo et al. 2003; Fathizadeh et al. 2011). When compared with conventional chemical treatment, biological treatment shows some advantages, such as low operational costs and easy recovery of this valuable metal (Mnif et al. 2009). A wide variety of bacteria have been reported to reduce $\mathrm{Cr}(\mathrm{VI})$ under either aerobic (Rehman et al. 2011) or anaerobic (Bhowmick et al. 2009) conditions.

Beside bacteria, plants especially hydrophytes can play an important role in metal removal via filtration, adsorption, cation exchange, and through plant-induced chemical changes in the rhizosphere (Hanc et al. 2009). The use of free-floating hydrophytes for the recovery of pollutants from wastewater represents an alternative technology with 
a significant potential for application in small and largescale industrial setups (Danh et al. 2009). Apart from supporting plant growth of the accumulating biomass, rhizosphere bacteria may mobilize heavy metals for enhanced uptake by plant roots ( $\mathrm{Li}$ et al. 2009). Hence, the present study focuses on the chromium detoxification potential of bacteria and hydrophytes alone and in combination under varying environmental conditions. The study was carried out in the Department of Microbiology and Molecular Genetics, University of the Punjab, Lahore, Pakistan in the year 2010.

\section{Materials and methods}

Bacterial isolation and characterizations

Effluent samples from tanneries situated in Din Garh, Kasur, Pakistan were collected in sterilized bottles/bags and were labelled according to the sample. Samples temperature and $\mathrm{pH}$ were recorded on site (Table 1). Physicochemical characteristics of soil (Sparks 1996) and wastewater (Clesceri et al. 1998) were also carried out. Serial dilutions $(1 / 10,1 / 100,1 / 1,000)$ of effluents and soil suspensions were made and plated on nutrient agar plates supplemented with $1,000 \mu \mathrm{g} \mathrm{ml}^{-1}$ of $\mathrm{K}_{2} \mathrm{CrO}_{4}$. The plates were incubated at $37^{\circ} \mathrm{C}$ for $24 \mathrm{~h}$ at $\mathrm{pH}$ 7. Colonies obtained were picked and purified by many rounds of streaking. Isolated strains were further characterized morphologically, biochemically, physiologically and genetically following Gerhardt et al. (1994). To confirm the identity of the three isolated strains, 16S rRNA gene sequencing was undertaken. 16S rRNA gene $(1,500 \mathrm{bp})$ was amplified and the amplicon sequenced using fluorescent di-deoxy terminator cycle sequencing chemistry. The extension product was then separated on an ABI PRISM automated DNA sequencer and compared the data to the MicroSeq ${ }^{\circledR}$ databases.
Collections of hydrophytes

Collected the Pistia stratiotes and Eichhornia crassipes plants in sterilized polyethylene bags from a freshwater pond of the University of the Punjab, Lahore, Pakistan, which had not been previously exposed to a contaminated environment. Plants were washed with tap water, blot dried and the weights of roots and shoots were recorded. Plants were grown in nutrient solution [grams per liter: $\mathrm{KNO}_{3} \quad 0.505 ; \mathrm{Ca}\left(\mathrm{NO}_{3}\right)_{2} \quad 0.820 ; \mathrm{NaH}_{2} \mathrm{PO}_{4} \cdot 7 \mathrm{H}_{2} \mathrm{O} \quad 0.208$; $\mathrm{MgSO}_{4} \cdot 7 \mathrm{H}_{2} \mathrm{O}$ 0.369; $\mathrm{FeC}_{6} \mathrm{H}_{5} \mathrm{O}_{7} 0.0245 ; \mathrm{MnSO}_{4}$ 0.00223; $\mathrm{CuSO}_{4} \cdot 5 \mathrm{H}_{2} \mathrm{O} 0.00024 ; \mathrm{ZnSO}_{4} \cdot 7 \mathrm{H}_{2} \mathrm{O} 0.000296 ; \mathrm{H}_{3} \mathrm{BO}_{3}$ 0.00186; $\left(\mathrm{NH}_{4}\right)_{6} \quad \mathrm{Mo}_{7} \mathrm{O}_{24} \cdot 4 \mathrm{H}_{2} \mathrm{O} \quad 0.000035 ; \mathrm{CoSO}_{4} \cdot 7 \mathrm{H}_{2} \mathrm{O}$ 0.000028; $\mathrm{CoSO}_{4} \cdot 7 \mathrm{H}_{2} \mathrm{O}$ 0.00585] (Hewitt 1963) and maintained in a growth chamber at a temperature of $25 \pm 2{ }^{\circ} \mathrm{C}$ with a $12 \mathrm{~h}$ photoperiod (10 Klux). Equal-sized plants were selected for each experiment.

\section{$\mathrm{Cr}(\mathrm{VI})$ reduction experiments}

For the bacterial $\mathrm{Cr}(\mathrm{VI})$ reduction experiment, $100 \mathrm{ml}$ of DeLeo and Ehrlich (1994) medium (grams per liter: tryptone 10 , yeast extract $5, \mathrm{NaCl} 5$, citric acid 1 and $\mathrm{Na}_{2} \mathrm{HPO}_{4}$ 6.9) was used supplemented with one of the three initial $\mathrm{K}_{2} \mathrm{CrO}_{4}$ concentrations $\left(100,500\right.$ and $1,000 \mu \mathrm{g} \mathrm{ml}^{-1}$ ). Following incubation by one of the three isolated strains of bacteria, cultures were maintained on incubating shaker with $150 \mathrm{rpm}$ at $37^{\circ} \mathrm{C}$. After $24 \mathrm{~h}$ of incubation, samples were taken aseptically and were analyzed for $\mathrm{Cr}(\mathrm{VI})$ reduction. The degree of reduction of $\mathrm{Cr}(\mathrm{VI})$ by bacterial strains was monitored in the supernatant of the cultures using the standard spectrophotometric method (Clesceri et al. 1998) by reacting with diphenylcarbazide in an acidic solution of phosphoric acid. The absorption was measured at $540 \mathrm{~nm}$. The effects of various temperatures $(28,37$ and $45^{\circ} \mathrm{C}$ ) on $\mathrm{Cr}(\mathrm{VI})$ reduction were also examined. Cultures were incubated at various temperatures and after $24 \mathrm{~h}$ incubation, $\mathrm{Cr}(\mathrm{VI})$ reduction was measured as described

Table 1 Physicochemical characteristics of wastewaterlsoils samples used for bacterial isolation

\begin{tabular}{|c|c|c|c|c|}
\hline $\begin{array}{l}\text { Bacterial } \\
\text { isolates }\end{array}$ & $\begin{array}{l}\text { Nature of } \\
\text { sample }\end{array}$ & Locality & Sample & Physicochemical characteristics \\
\hline CrSS4 & Contaminated soil & $\begin{array}{r}\text { Din Garh } \\
\text { (Kasur) }\end{array}$ & A3 & $\begin{array}{l}\mathrm{pH} 6 \text {, EC 58, Cr(VI) } 310 \mu \mathrm{g} \mathrm{g}^{-1} ; \text { Fe } 18 \mu \mathrm{g} \mathrm{g}^{-1} ; \mathrm{Cu} 10 \mu \mathrm{g} \mathrm{g}^{-1} ; \mathrm{Zn} 7 \mu \mathrm{g} \mathrm{g}^{-1} \text {; } \\
\quad \text { Ni } 7 \mu \mathrm{g} \mathrm{g}^{-1} ; \text { Co } 2 \mu \mathrm{g} \mathrm{g}^{-1} ; \mathrm{Mn} 14 \mu \mathrm{g} \mathrm{g}^{-1} \text {, Organic matter } 285\end{array}$ \\
\hline CrSS5 & Contaminated soil & $\begin{array}{r}\text { Din Garh } \\
\text { (Kasur) }\end{array}$ & B4 & $\begin{array}{l}\text { pH 6.4, EC 30, Cr(VI) } 211 \mu \mathrm{g} \mathrm{g}^{-1} ; \mathrm{Fe} 14 \mu \mathrm{g} \mathrm{g}^{-1} ; \mathrm{Cu} 12 \mu \mathrm{g} \mathrm{g}^{-1} ; \mathrm{Zn} 9 \mu \mathrm{g} \mathrm{g}^{-1} \text {; } \\
\text { Ni } 4 \mu \mathrm{g} \mathrm{g}^{-1} ; \text { Co } 3 \mu \mathrm{g} \mathrm{g}^{-1} ; \mathrm{Mn} 12 \mu \mathrm{g} \mathrm{g}^{-1} \text {, Organic matter } 347\end{array}$ \\
\hline CrSS8 & Wastewater & $\begin{array}{r}\text { Din Garh } \\
\text { (Kasur) }\end{array}$ & D2 & 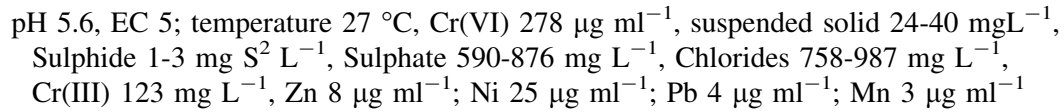 \\
\hline
\end{tabular}


above. The initial $\mathrm{K}_{2} \mathrm{CrO}_{4}$ concentration used for this experiment was 100 and $1,000 \mu \mathrm{g} \mathrm{ml}^{-1}$. The reduction potential of these bacterial strains was also examined at various pH levels (5, 7 and 9) using DeLeo and Ehrlich (1994) medium supplemented with an initial $\mathrm{K}_{2} \mathrm{CrO}_{4}$ concentration of 100 and $1,000 \mu \mathrm{g} \mathrm{ml}^{-1}$. The $\mathrm{pH}$ and temperature of the reduction medium was controlled during the experiment. The $\mathrm{Cr}(\mathrm{VI})$ reduced after $24 \mathrm{~h}$ was determined as mentioned above.

The effects of different heavy metals on chromium reduction by the bacterial strains were also studied. For this purpose, cultures were also separately amended with salts of $\mathrm{ZnSO}_{4} 50 \mu \mathrm{g} \mathrm{ml}^{-1}, \mathrm{CuSO}_{4} 50 \mu \mathrm{g} \mathrm{ml}^{-1}$ and $\mathrm{MnSO}_{4} 50 \mu \mathrm{g} \mathrm{ml}^{-1}$ at initial $\mathrm{Cr}(\mathrm{VI})$ concentrations of $100 \mu \mathrm{g} \mathrm{ml}^{-1}$. Incubation took place at $37{ }^{\circ} \mathrm{C}$ and $\mathrm{pH}$ 7.0. After $24 \mathrm{~h}$, cultures were harvested, and were processed as described above to determine the amount of $\mathrm{Cr}(\mathrm{VI})$ reduced to $\mathrm{Cr}$ (III).

\section{Removal of $\mathrm{Cr}(\mathrm{VI})$ by hydrophytes and bacteria}

The effects of bacterial strains on $\mathrm{Cr}(\mathrm{VI})$ removal/detoxification in conjunction with Pistia stratiotes and Eichhornia crassipes were examined at three $\mathrm{pH}$ levels (5, 7 and 9) in aqueous solutions with no nutritional ingredients added to the test at an initial $\mathrm{K}_{2} \mathrm{CrO}_{4}$ concentration of $300 \mu \mathrm{g} \mathrm{ml}^{-1}$. A bacterial inoculum of $100 \mu \mathrm{l}$ of a freshly prepared overnight culture was added to the solution with incubation at ambient temperature.

After 15 days of incubation, cultures were harvested and $\mathrm{Cr}$ (VI) reduction was determined both in plants and bacteria as described by Rand et al. (1979). Weighed plant material ( $1 \mathrm{~g}$ ) was taken in two labeled (respective treatment) flasks and digested. $10 \mathrm{ml}$ of $\mathrm{HNO}_{3}, 2 \mathrm{ml}$ of $\mathrm{HClO}_{4}$ were added in each flask and flasks were heated on sand bath. In the beginning brown fumes of $\mathrm{HNO}_{3}$ were emitted from flask, but later on flasks were full with white fumes. When solutions become clear, flasks were removed from sand bath and after cooling volume were made up to $15 \mathrm{ml}$ with distilled water. Samples were now ready for chromium estimation. Bacterial pellet was also digested by the same method, and all samples were analyzed for cell chromium content. Standard errors of the means were calculated following Steel and Torrie (1981).

\section{Biochemical analysis}

Many bacterial strains produce phytohormone auxin which benefits plant growth. Auxin production was estimated following Mahadevan (1984). Plant material was crushed and transferred into properly labeled test tubes. $2 \mathrm{ml}$ of ethyl ether was added in each test and covered tightly to avoid evaporation of ethyl ether and shaked thoroughly. They were kept at $4{ }^{\circ} \mathrm{C}$ for $4 \mathrm{~h}$. After extraction of samples, $2 \mathrm{ml}$ of sodium bicarbonate was added in sample tubes and was thoroughly mixed. $1 \mathrm{ml}$ of $5 \%$ sodium bicarbonate was added in each test tube having supernatant, and was shaked thoroughly and sodium bicarbonate layer was transferred into other set of properly labeled respective test tubes. This process was repeated twice. The bicarbonate extraction was acidified to $\mathrm{pH} 3$ with $\mathrm{HCl}(6 \mathrm{~N}) .1 \mathrm{ml}$ of ethyl ether was added in each test tube having bicarbonate extract. The inorganic layer was separated and discarded and in the residue (organic layer) $2 \mathrm{ml}$ of Salkowski reagent was added in each test tube. A blank was also prepared by adding $1 \mathrm{ml}$ of ethyl ether and $2 \mathrm{ml}$ of Salkowski reagent. All test tubes were kept in dark at room temperature for color development for 25-30 min. Auxin content in the extract was estimated with the help of Beckman D-2 Spectrophotometer at $535 \mathrm{~nm}$ wavelengths. Optical densities of various concentrations of IAA (standard) were also measured.

Under stress condition, bacteria also produce acid phosphatase. The enzyme was extracted following the method of Iqbal and Rafique (1987). Plant material was crushed in cold $0.1 \mathrm{M}$ Tris $\mathrm{HCl}$ buffer ( $\mathrm{pH}$ 6.5) with $4: 1$ (v/w) ratio of buffer to plant material. The crushed material was centrifuged at 14,000 rpm for $10 \mathrm{~min}$. Pellet obtained was discarded and supernatant thus obtained was used for the estimation of enzyme acid phosphatase. As a consequence of hydrolysis of acid phosphatase, phenol was released from the substrate phenyl phosphate under specific conditions of time, temperature and $\mathrm{pH}$. To observe the activity of acid phosphatase enzyme, the time duration was $1 \mathrm{~h}$, temperature was $37^{\circ} \mathrm{C}$ and $\mathrm{pH}$ was 4.9. For the quantitative estimation of enzyme, series of reactions i.e., test, control, standard and blank were carried out.

In test reaction, $1 \mathrm{ml}$ of citrate buffer $\mathrm{pH} 4.9$ was mixed with $1 \mathrm{ml}$ of substrate phenyl in properly labeled set of test tube. The set was placed in water bath at $37{ }^{\circ} \mathrm{C}$ for $3 \mathrm{~min}$. After incubation, $0.2 \mathrm{ml}$ of enzyme extract was added and incubated again at $37^{\circ} \mathrm{C}$ for $1 \mathrm{~h}$. Then, $1 \mathrm{ml}$ of $0.5 \mathrm{~N} \mathrm{NaOH}$ was added. In control, $1 \mathrm{ml}$ of citrate buffer $\mathrm{pH} 4.9$ was mixed with $1 \mathrm{ml}$ of substrate phenol. The samples were incubated at $37{ }^{\circ} \mathrm{C}$ for $1 \mathrm{~h}$ in water bath. After that $1 \mathrm{ml}$ of $0.5 \mathrm{~N} \mathrm{NaOH}$ was added followed by $0.2 \mathrm{ml}$ of enzyme extract in each tube and mixed thoroughly. In standard, $1.2 \mathrm{ml}$ of citrate buffer (pH 4.9), $1 \mathrm{ml}$ of phenol standard and $1 \mathrm{ml}$ of $0.5 \mathrm{~N}$ $\mathrm{NaOH}$ were mixed together in a test tube, which was used 


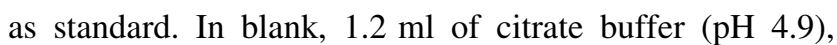
$1 \mathrm{ml}$ of distilled water and $1 \mathrm{ml}$ of $0.5 \mathrm{~N} \mathrm{NaOH}$ was added. Test tube containing this mixture is treated as blank. In all the tubes (test, control, standard and blank), $1 \mathrm{ml}$ of $0.5 \mathrm{~N}$ sodium bicarbonate was added followed by the addition of $1 \mathrm{ml}$ of 4-aminoantipyrine solution and $1 \mathrm{ml}$ of potassium ferricyanide solution. Test tubes were gently shaked and the optical density was taken immediately against water at $510 \mathrm{~nm}$ on spectrophotometer. The total enzyme activity was calculated by using the following formula,

Acid phosphatase (K.A units $/ 100 \mathrm{ml}$ )

$$
=T-C /(S-B) \times W
$$

where K.A unit is the liberation of $1 \mathrm{mg}$ of phenol in $1 \mathrm{~h}$. $T$ is absorption of test, $C$ is absorption of control, $S$ is absorption of standard, $B$ is absorption of blank, $W$ is weight of plant material $(\mathrm{g})$.

\section{Root colonization study}

To study the bacterial colonization, roots of Pistia stratiotes and Eichhornia crassipes were surface sterilized and were inoculated with bacterial suspension and control roots were treated with sterilized distilled water. Plants were grown for 15 days at an initial $\mathrm{Cr}(\mathrm{VI})$ concentration of $300 \mu \mathrm{g} \mathrm{ml}^{-1}$ and then harvested to test the colonization potential of introduced bacterial strains. To confirm the surface colonization of bacteria, the plant roots were treated with $0.01 \%$ tetrazolium dye. After tetrazolium treatment, the plant roots turned pink on portions where bacterial cells were present. Un-inoculated control plants showed no pink coloration after tetrazolium treatment. The study of root surfaces under microscope revealed that the portions of roots which were stained darker had much dense surface bacterial population than the lighter stained roots. To assess the intensity of bacterial root colonization, the bacterial strains on rhizoplane and in the rhizosphere were also estimated by culturing on L.agar medium.

\section{Results and discussion}

\section{Strains characterizations}

Industries are discharging hazardous chemicals in their wastewaters which find their way into fresh water rivers and streams (Tarcan et al. 2010). The present research work deal with the reduction of $\mathrm{Cr}(\mathrm{VI})$ chromium by chromium-resistant bacterial strains in conjunction with hydrophytes. Strain CrSS8 was isolated from wastewater sample D2 while strains CrSS4 and CrSS5 were isolated from contaminated soil samples A3 and B4, respectively (Table 1). These strains could resist very high concentrations of $\mathrm{K}_{2} \mathrm{CrO}_{4}$ both in L.agar (up to $25 \mathrm{mg} \mathrm{ml}^{-1}$ ) and acetate minimal medium $\left(2 \mathrm{mg} \mathrm{ml}^{-1}\right)$. Strain CrSS4 is a gram-positive aerobic spore-forming rod, while strain CrSS5 is gram-negative facultative anaerobic motile rod. Strain CrSS8 is gram-positive, aerobic and motile cocci (Table 2). All the strains are capable of hydrolyzing starch. On the basis of 16S rRNA ribotyping, strains CrSS4, CrSS5 and CrSS8 were identified as Bacillus pumilus-S4, Pseudomonas doudoroffi-S5 and Exiguobacterium-S8, respectively.

To assess the heavy metal resistance profile of the bacteria, six heavy metals $\left(\mathrm{HgCl}_{2}, \mathrm{CdCl}_{2}, \mathrm{CuSO}_{4}, \mathrm{ZnSO}_{4}\right.$, $\mathrm{MnSO}_{4}$, and $\mathrm{Na}_{2} \mathrm{HAsO}_{4}$ ) were used. A variable response towards different metals was observed for each strain at different concentrations of the respective metal salts (Table 3). All the strains showed resistance against $\mathrm{Na}_{2} \mathrm{HAsO}_{4}$ up to $1,500 \mu \mathrm{g} \mathrm{ml}^{-1}$, whereas only strain Exiguobacterium-S8 was resistant to all the metals at the highest concentrations used in this study (Table 3). For $\mathrm{HgCl}_{2}$ the highest concentration of $150 \mu \mathrm{g} \mathrm{ml}^{-1}$ was tolerated by strains Pseudomonas doudoroffii-S5 and Exiguobacterium-S8 (Table 3). This high level resistance against $\mathrm{Cr}(\mathrm{VI})$ and other metals helps these strains to survive in metal-polluted environment. Chromium-resistant bacteria isolated by Horton et al. (2006) found to be resisting $\mathrm{Cr}(\mathrm{VI})$ up to $1,000 \mu \mathrm{g} \mathrm{ml}^{-1}$ while in another study by Camargo et al. (2003), bacterial strains tolerated $\mathrm{Cr}(\mathrm{VI})$ up to $2,500 \mu \mathrm{g} \mathrm{ml}^{-1}$ initial concentration. The temperature and $\mathrm{pH}$ for optimum growth of these strains is $37^{\circ} \mathrm{C}$ and 7 , respectively.

\section{$\mathrm{Cr}(\mathrm{VI})$ reduction}

A variable response in terms of reduction potential was observed by the three strains at different initial $\mathrm{Cr}(\mathrm{VI})$ concentrations. Strains Bacillus pumilus-S4, Pseudomonas doudoroffii-S5 and Exiguobacterium-S8 showed 82.4, 71.2 and $52.1 \%$ reduction respectively, from an initial $\mathrm{Cr}(\mathrm{VI})$ concentration of $100 \mu \mathrm{g} \mathrm{ml}^{-1}$ (Fig. 1). The percentage $\mathrm{Cr}(\mathrm{VI})$ reduction in Pseudomonas doudoroffii-S5 was greater [ $8.27 \mathrm{mg} \mathrm{Cr}(\mathrm{VI}) 24 \mathrm{~h}^{-1}$ ] at a lower initial $\mathrm{K}_{2} \mathrm{CrO}_{4}$ concentration $\left(100 \mu \mathrm{g} \mathrm{ml}^{-1}\right)$ but overall more chromate [28.4 mg Cr(VI) $24 \mathrm{~h}^{-1}$ ] was reduced at a higher initial $\mathrm{Cr}(\mathrm{VI})$ concentration $\left(1,000 \mu \mathrm{g} \mathrm{ml}^{-1}\right)$ (Fig. 1). Wang and Xiao (1995) showed that the rate of $\mathrm{Cr}(\mathrm{VI})$ reduction by Bacillus sp. increased with initial $\mathrm{Cr}(\mathrm{VI})$ concentrations ranging from 20 to $70 \mu \mathrm{g} \mathrm{ml}^{-1}$ and decreased at higher 
Table 2 Morphological and biochemical characteristics of strains

\begin{tabular}{|c|c|c|c|c|c|c|c|}
\hline \multirow{2}{*}{ Characteristics } & \multicolumn{3}{|l|}{ Strains } & \multirow[t]{2}{*}{ Characteristics } & \multicolumn{3}{|l|}{ Strains } \\
\hline & CrSS4 & CrSS5 & CrSS8 & & CrSS4 & CrSS5 & CrSS8 \\
\hline Colony shape & Concentric & Round & Filamentous & Lactose & - & + & - \\
\hline Colony elevation & Flat & Convex & Convex & D-mannitol & + & + & - \\
\hline Colony size $(\mathrm{mm})$ & 1.9 & 3.6 & 3.9 & Inositol & - & - & - \\
\hline Colony margin & Irregular & Entire & Entire & D-sorbitol & - & - & - \\
\hline Cell shape & Rod & Rod & Cocci & L-rhamnose & - & - & - \\
\hline Cell size $(\mu \mathrm{m})$ & $0.5-1.2$ & $0.6-1.0$ & $0.7-0.7$ & D-sucrose & + & + & + \\
\hline Gram staining & G+ & $\mathrm{G}-$ & $\mathrm{G}+$ & D-melibiose & - & - & - \\
\hline Capsules staining & + & + & + & Amygdalin & + & - & + \\
\hline Spore staining & + & - & - & L-Arabinose & + & - & + \\
\hline Motility & - & + & + & Maltose & + & + & + \\
\hline 2-Nitrophenyl-D-galactopyranoside & + & - & - & Oxidase & - & + & + \\
\hline L-lysine & - & - & - & Catalase & + & + & + \\
\hline L-ornithine & - & - & - & Nitrate reduction & - & + & + \\
\hline Urea & - & - & - & OF test & A & FA & A \\
\hline L-tryptophane & - & - & + & Gas production & - & - & - \\
\hline Indole production & - & - & - & Starch hydrolysis & + & + & + \\
\hline Gelatin & + & - & + & Arginine hydrolysis & - & + & - \\
\hline
\end{tabular}

OF Oxidation fermentation, - negative, + positive, $A$ aerobic, $F A$ facultative anaerobic

Table 3 Heavy metals resistance profile of chromium-resistant bacterial strains

\begin{tabular}{lllrrrr}
\hline Strains & \multicolumn{3}{l}{ Heavy metals $\left(\mu \mathrm{g} \mathrm{m}{ }^{-1}\right)$} & & \\
\cline { 2 - 7 } & $\mathrm{Hg}^{2+} 200$ & $\mathrm{Cd}^{2+} 200$ & $\mathrm{Cu}^{2+} 1,500$ & $\mathrm{Zn}^{2+} 1,500$ & $\mathrm{Mn}^{2+} 1,500$ & $\mathrm{As}^{3+} 1,500$ \\
\hline Bacillus pumilus-S4 & 100 & 200 & 1,500 & 1,000 & 1,500 & 1,500 \\
Pseudomonas doudoroffii-S5 & 150 & 200 & 500 & 500 & 1,000 & 1,500 \\
Exiguobacterium-S8 & 150 & 200 & 1,500 & 1,500 & 1,500 & 1,500 \\
\hline
\end{tabular}

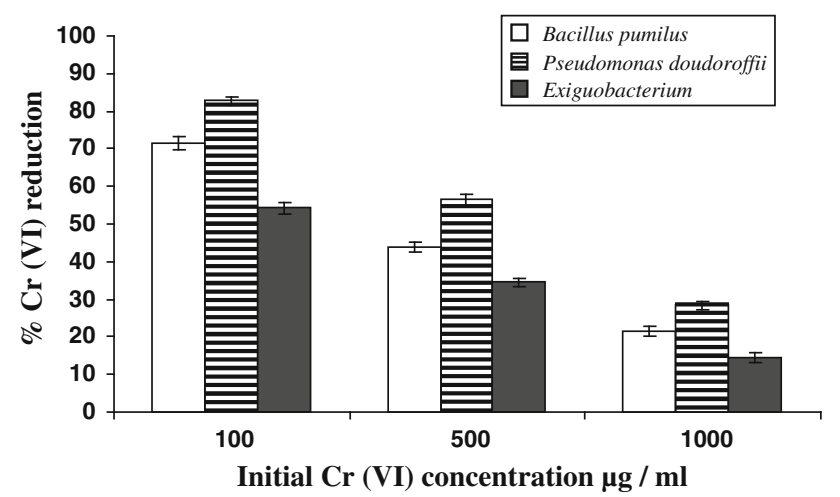

Fig. 1 Hexavalent chromium reduction potential of bacterial strains at different initial $\mathrm{K}_{2} \mathrm{CrO}_{4}$ concentrations of 100,500 and $1,000 \mu \mathrm{g} \mathrm{ml}^{-1}$ after $24 \mathrm{~h}$ of incubation at $37^{\circ} \mathrm{C}$ and $\mathrm{pH} 7$

concentrations. Another study by Camargo et al. (2003), revealed that chromium-resistant bacteria can tolerate $2,500 \mu \mathrm{g} \mathrm{ml}^{-1}$ of $\mathrm{Cr}(\mathrm{VI})$, but most of the isolates reduced
$\mathrm{Cr}(\mathrm{VI})$ at concentrations lower than $1,500 \mu \mathrm{g} \mathrm{ml} \mathrm{g}^{-1}$. In contrast to the others studies, the strains used in the present study can resist and reduce much high concentration of chromate.

To assess the effect of various $\mathrm{pH}$ on chromium reduction, three $\mathrm{pH}$ levels $(5,7$ and 9$)$ were selected at initial $\mathrm{Cr}(\mathrm{VI})$ concentration of 100 and $1,000 \mu \mathrm{g} \mathrm{ml} \mathrm{m}^{-1}$. After $24 \mathrm{~h}$ incubation, it was found that strains showed reduction potential at different $\mathrm{pH}$ values, but maximum reduction was observed at $\mathrm{pH} 7$ (Fig. 2a, b). Pseudomonas doudoroffii-S5 reduced 74.6 and $32.4 \%$ of $\mathrm{Cr}(\mathrm{VI})$ at initial $\mathrm{Cr}(\mathrm{VI})$ concentration of 100 and $1,000 \mu \mathrm{g} \mathrm{ml}{ }^{-1}$, respectively, at pH 7 (Fig. 2a, b). Strains Bacillus pumilus-S4, and Exiguobacterium-S8 reduced maximum $\mathrm{Cr}(\mathrm{VI})$ at $\mathrm{pH} 7$ at both 100 and $1,000 \mu \mathrm{g} \mathrm{ml}^{-1}$ initial $\mathrm{Cr}(\mathrm{VI})$ concentration (Fig. 2a, b).

The optimum temperature for maximum $\mathrm{Cr}(\mathrm{VI})$ reduction for the three strains was $37^{\circ} \mathrm{C}$ but also took place at both 28 and $45{ }^{\circ} \mathrm{C}$ when initially supplied with 100 or 
Fig. 2 Hexavalent chromium reduction potential of bacterial strains at different initial $\mathrm{pH}(5$, 7 and 9) and temperature (28, 37 and $45{ }^{\circ} \mathrm{C}$ ) after $24 \mathrm{~h}$ of incubation when initially supplied with $100(\mathbf{a}, \mathbf{c})$ and $1,000(\mathbf{b}, \mathbf{d}) \mu \mathrm{g} \mathrm{ml}^{-1}$ of $\mathrm{K}_{2} \mathrm{CrO}_{4}$ $\mathbf{a}$

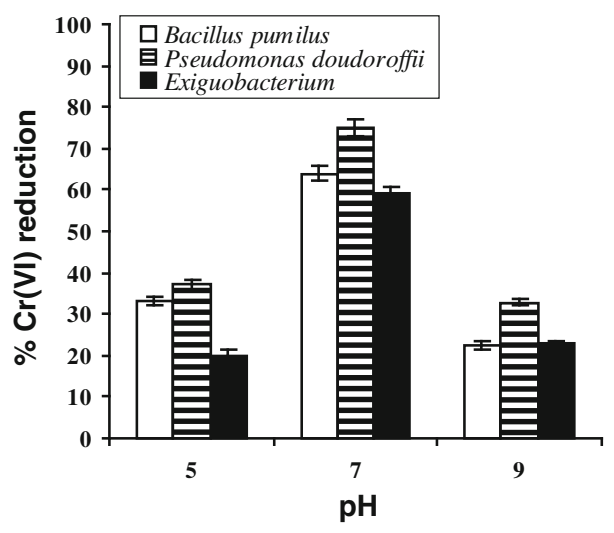

c

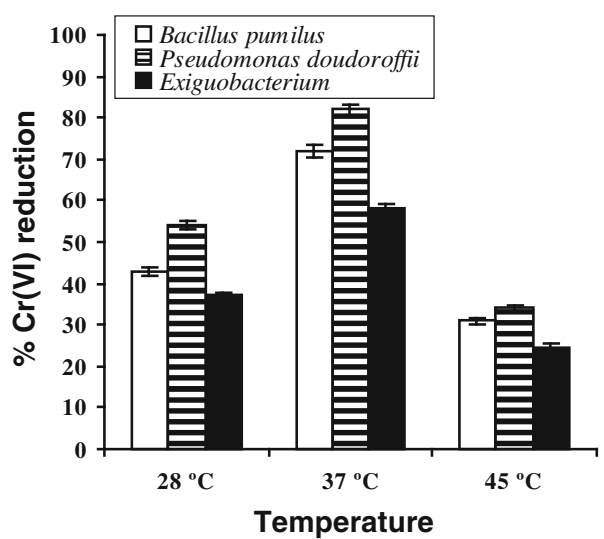

b

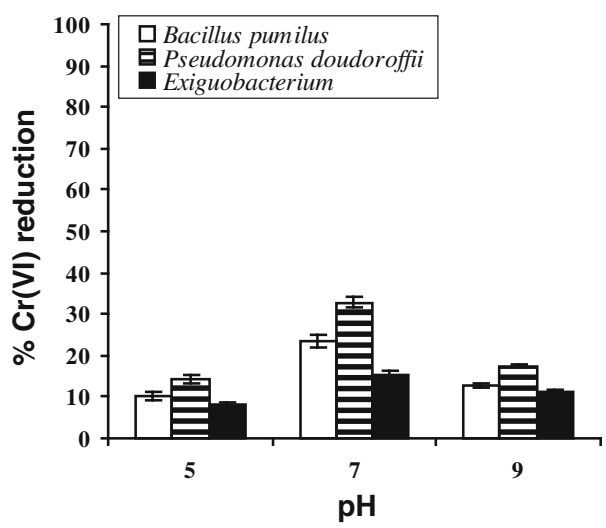

d

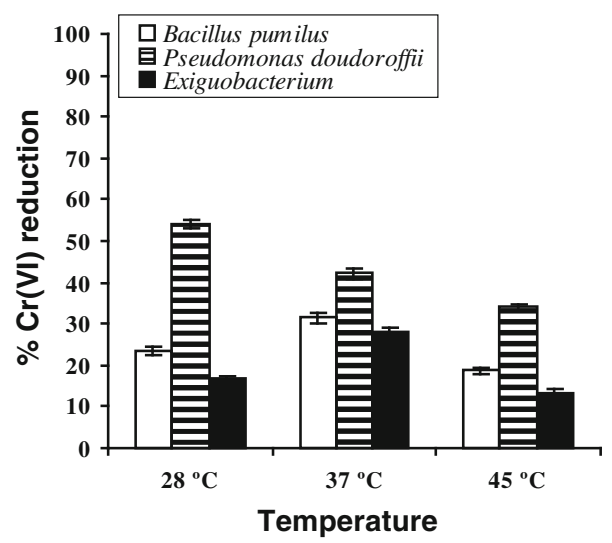

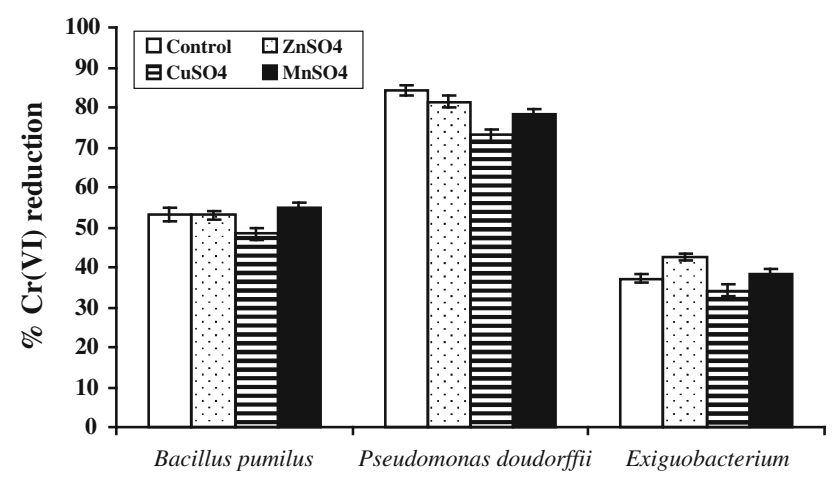

Fig. 3 Hexavalent chromium reduction potential of bacterial strains in the presence of various heavy metals $\left(\mathrm{ZnSO}_{4}, \mathrm{CuSO}_{4}\right.$ and $\left.\mathrm{MnSO}_{4}\right)$ at an initial concentration of $50 \mu \mathrm{g} \mathrm{ml}^{-1}$. The initial $\mathrm{Cr}(\mathrm{VI})$ concentration used was $100 \mu \mathrm{g} \mathrm{ml}^{-1}$ at $\mathrm{pH} 7$ and $37^{\circ} \mathrm{C}$ for $24 \mathrm{~h}$ incubation period

$1,000 \mu \mathrm{g} \mathrm{ml}^{-1}$ of $\mathrm{K}_{2} \mathrm{CrO}_{4}$. Interestingly, strain Pseudomonas doudoroffii-S5 reduced maximum $\mathrm{Cr}(\mathrm{VI})$ at $45^{\circ} \mathrm{C}$ when initially supplied with $1,000 \mu \mathrm{g} \mathrm{ml}^{-1}$ of $\mathrm{K}_{2} \mathrm{CrO}_{4}$ (Fig. 2c, d). However, its percentage reduction was more at
$28{ }^{\circ} \mathrm{C}$ when initial $\mathrm{Cr}(\mathrm{VI})$ concentration was $100 \mu \mathrm{g} \mathrm{ml}{ }^{-1}$ of $\mathrm{K}_{2} \mathrm{CrO}_{4}$. Komori et al. (1990) showed that bacteria can reduce chromium at an optimal temperature of $37^{\circ} \mathrm{C}$, whereas in another study conducted by Dhal et al. (2010), the chromate reduction in Bacillus sp. was more than $90 \%$ at initial $\mathrm{Cr}(\mathrm{VI})$ concentration of $100 \mathrm{mg} \mathrm{L}^{-1}$ after $144 \mathrm{~h}$ at a temperature of $35^{\circ} \mathrm{C}$.

Overall, the reduction potential of the strain Pseudomonas doudoroffii-S5 slightly decreased 3.4, 8.9 and $6.05 \%$ with the addition of $\mathrm{ZnSO}_{4}, \mathrm{CuSO}_{4}$ and $\mathrm{MnSO}_{4}$, respectively, at $50 \mu \mathrm{g} \mathrm{ml}^{-1}$. In case of strain Bacillus pumilus-S4, the addition of heavy metals had no impact on its reduction potential apart from $\mathrm{CuSO}_{4}$ where a slight decrease (8.2\%) was observed (Fig. 3). In case of Exiguobacterium-S8, addition of $\mathrm{ZnSO}_{4}$ and $\mathrm{MnSO}_{4}$ resulted 13 and $8.1 \%$ increment, while $\mathrm{CuSO}_{4}$ caused $5 \%$ decreased in the reduction potential (Fig. 3).

Effect of hydrophytes on $\mathrm{Cr}(\mathrm{VI})$ reduction

Most of the strains and plant showed increased reduction at $\mathrm{pH}$ 7. After 15 days, it was observed that the reduced levels 

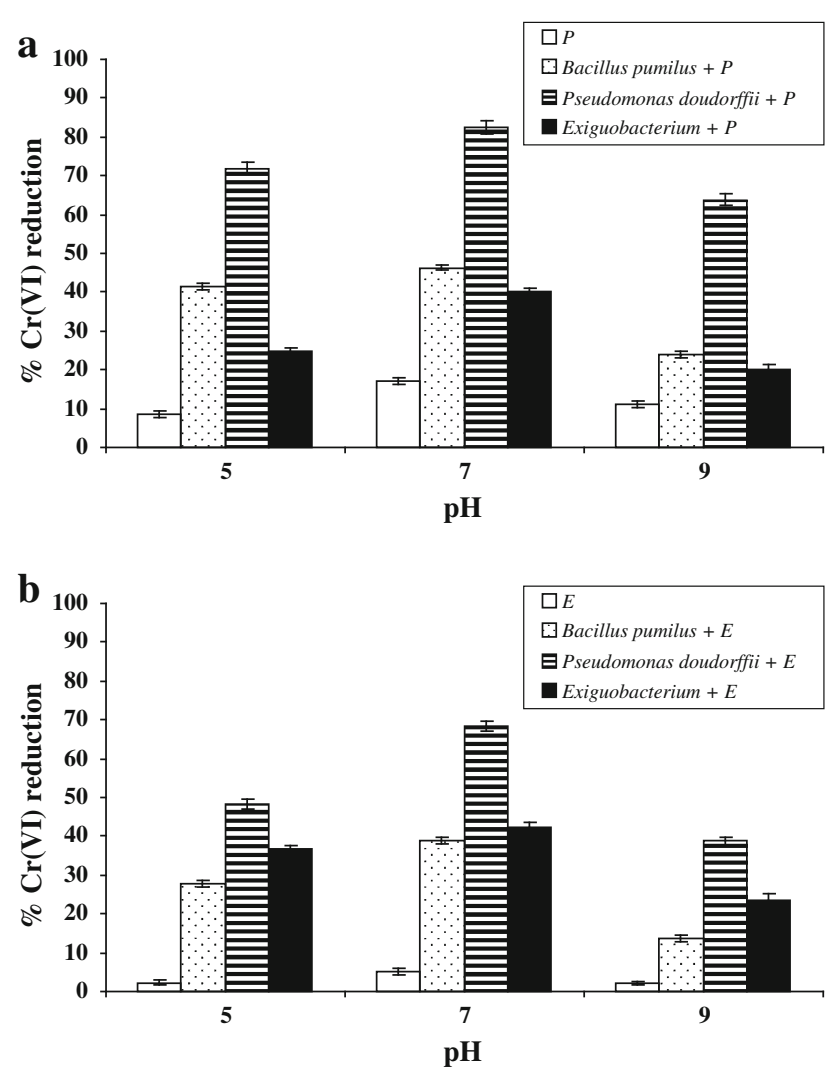

Fig. 4 Hexavalent chromium reduction potential of bacterial strains in the presence of a Pistia stratiotes and b Eichornia crassipes at an initial $\mathrm{K}_{2} \mathrm{CrO}_{4}$ concentration of $300 \mu \mathrm{g} \mathrm{ml}{ }^{-1}$ for 15 days at $37{ }^{\circ} \mathrm{C}$. $P$ stands for Pistia stratiotes and $E$ for Eichornia crassipes. Plants were used alone $(\mathrm{P}, \mathrm{E})$ as well as in combination $(\mathrm{P}+$ Bacillus pumilus-S4, $\mathrm{P}+$ Pseudomonas doudoroffii-S5, $\mathrm{P}+$ Exiguobacterium-S8 and E + Bacillus pumilus-S4, E + Pseudomonas doudoroffi$\mathrm{S} 5, \mathrm{E}+$ Exiguobacterium-S8) with each strain

of $\mathrm{Cr}(\mathrm{VI})$ was less in Pistia stratiotes as compared to Eichornia crassipes at various $\mathrm{pH}$. Pistia stratiotes reduced more $\mathrm{Cr}(\mathrm{VI})$ at $\mathrm{pH} 7$ as compared to $\mathrm{pH} 5$ and 9 where a very low amount of chromium was detected (Fig. 4a). When bacterial strains were used in combination with Pistia stratiotes, it was found that strain Pseudomonas doudoroffi-S5 reduced $78.6 \%$ of $\mathrm{Cr}(\mathrm{VI})$ at $\mathrm{pH} 7$ (Fig. 4a). In this case, the $\mathrm{Cr}(\mathrm{VI})$ reducing efficiency of strain $E x$ iguobacterium-S8 was much better and it reduced more chromate as compared to strain Bacillus pumilus-S4 at all $\mathrm{pH}$ levels (5, 7 and 9) in the presence of Pistia stratiotes. Eichhornia crassipes reduced 8.2, 14.8 and $11.3 \%$ of $\mathrm{Cr}(\mathrm{VI})$ from the aqueous solution when initially supplied with $300 \mu \mathrm{g} \mathrm{ml}^{-1}$ of $\mathrm{K}_{2} \mathrm{CrO}_{4}$ (Fig. 4b) at pH of 5, 7 and 9, respectively. In the presence of Eichornia crassipes, strains Bacillus pumilus-S4, Pseudomonas doudoroffii-S5 and Exiguobacterium-S8 reduced 83, 44.7 and $38.4 \%$ of $\mathrm{Cr}(\mathrm{VI})$, respectively, at pH 7. Becerra-Castro et al. (2009) investigated bacterial assisted phytoremediation where bacterial strains could solubilise $\mathrm{Ni}$ in the soil and potentially improve phytoextraction strategies. The endophytic fungi Neotyphodium not only increase the host plant tolerance to cadmium stress, but also caused more accumulation of $\mathrm{Cd}$ in root and shoot of Festuca arundinacea and Festuca pratensis (Soleimani et al. 2010). In another study by Abou-Shanab et al. (2003), chromium-resistant bacteria helps Eichornia crassipes plants for the removal/phytoremediation of chromium in wastewater.

Biochemical analysis

In general, there was a pronounced increase in the auxin content of Eichornia crassipes plants inoculated with bacterial strains but maximum increase in this parameter was observed in case of Pseudomonas doudoroffii-S5 where it was $3.42 \mu \mathrm{g} \mathrm{g}^{-1}$ fresh weight as compared to noninoculated control Eichornia crassipes plants where it was $1.31 \mu \mathrm{g} \mathrm{g}^{-1}$ fresh weight (Fig. 5a). Almost same trend was observed by inoculating Pseudomonas doudoroffi-S5 ( $2.83 \mu \mathrm{g} \mathrm{g}^{-1}$ fresh weight) in case of Pistia stratiotes plants when compared with non-inoculated control plants (1.72 $\mu \mathrm{g} \mathrm{g}^{-1}$ fresh weight) (Fig. 5a).

Eichornia crassipes plants which were inoculated with bacterial strain Pseudomonas doudoroffi-S5 showed significant increment $\left(9.28 \mu \mathrm{g} \mathrm{g}^{-1}\right.$ fresh weight) in the activity of acid phosphate enzyme when compared with non-inoculated control plants $\left(5.8 \mu \mathrm{g} \mathrm{g}^{-1}\right.$ fresh weight) (Fig. 5b). Although in case of Pistia stratiotes, strain Pseudomonas doudoroffii-S5, resulted an enhancement (10.18 $\mu \mathrm{g} \mathrm{g}^{-1}$ fresh weight) of acid phosphatase activity in comparison to that of non-inoculated control plants (5.26 $\mu \mathrm{g} \mathrm{g}^{-1}$ fresh weight) (Fig. 5b).

\section{Root colonization study}

It was observed that the number of bacterial cells present on the rhizoplane of roots was much higher as compared to the surrounding rhizosphere $(1-5 \mathrm{~cm})$ (Fig. 6). In both plants Eichhornia crassipes and Pistia stratiotes, the bacterial strains occupy the rhizoplane with high intensity (13 to 16 -folds) when compared with rhizosphere at $1 \mathrm{~cm} \mathrm{a}$ distance from root. In addition, this intensity decreased with the increase in distance (Fig. 6). The present study showed that the combined action of hydrophytes and bacterial strains resulted more removal/reduction of $\mathrm{Cr}(\mathrm{VI})$ from the aqueous solution. These strains Bacillus pumilusS4, Pseudomonas doudoroffii-S5 and Exiguobacterium-S8 live in the vicinity of Pistia stratiotes and Eichornia crassipes roots which were evident in the colonization study (Fig. 6). Plant roots release up to $20 \%$ of the total 
Fig. 5 Impact of bacterial strains on a auxin and $\mathbf{b}$ acid phosphatase production in the Pistia stratiotes and Eichornia crassipes plants grown at an initial concentration of $300 \mu \mathrm{g} \mathrm{ml}^{-1}$ of $\mathrm{K}_{2} \mathrm{CrO}_{4}$ at $\mathrm{pH} 7$ and $37^{\circ} \mathrm{C}$ for 15 days of incubation period
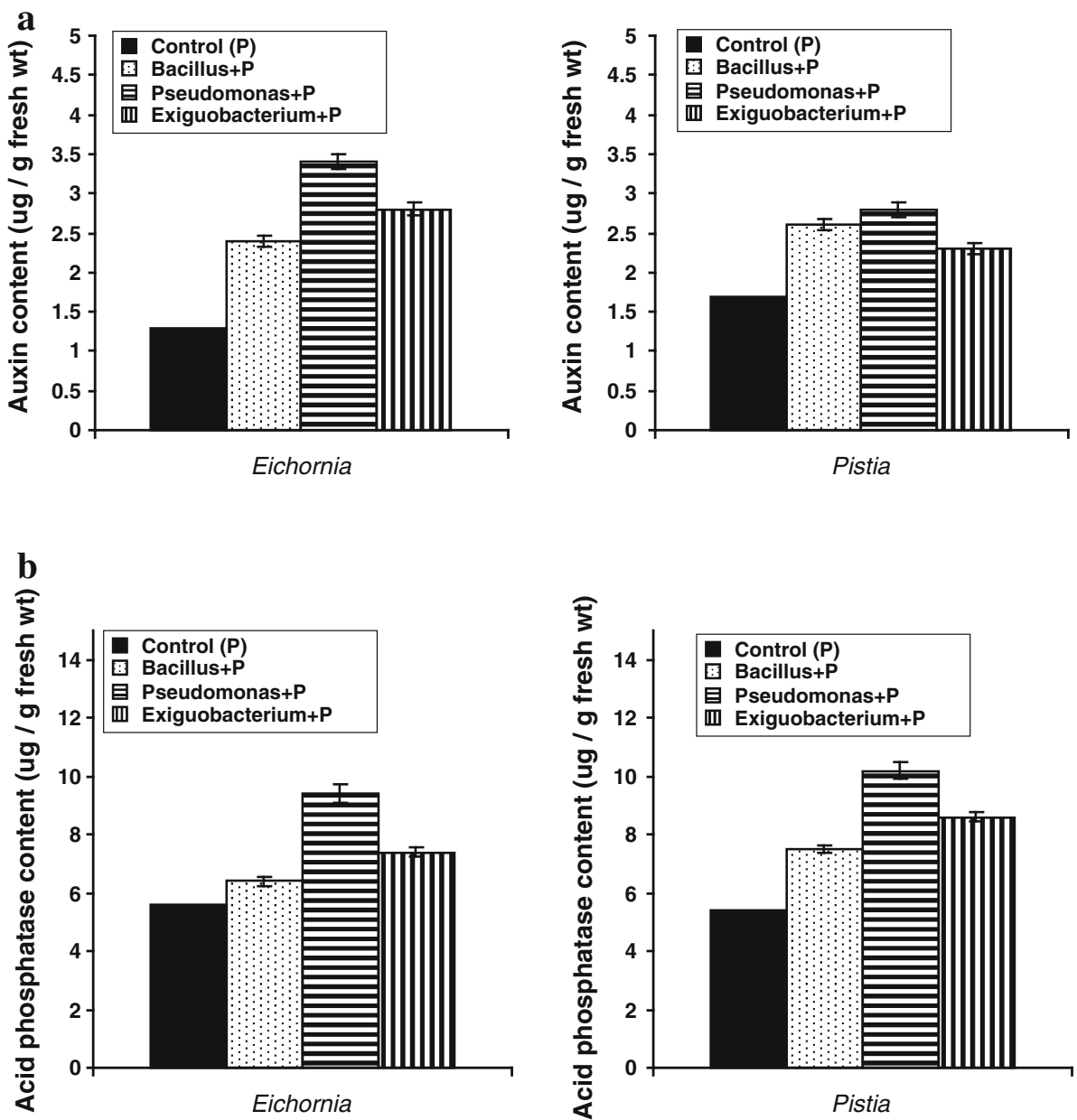

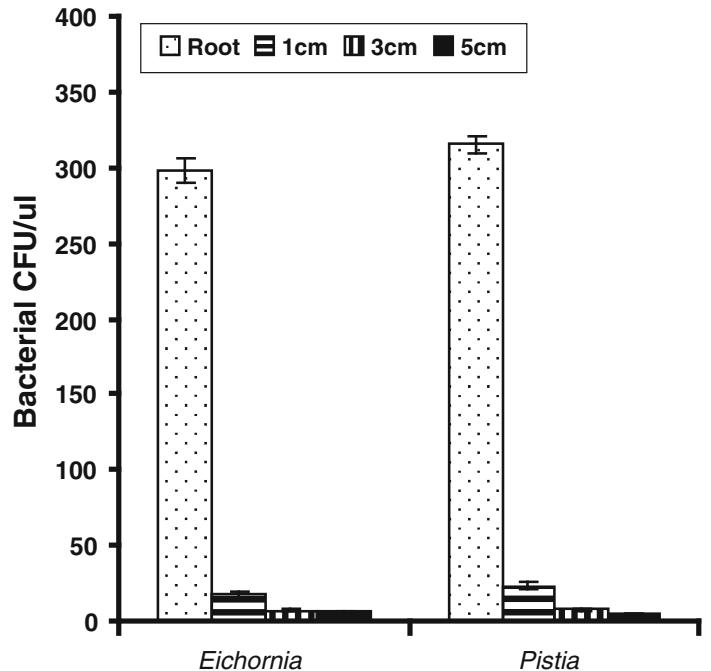

Fig. 6 Root colonization study of Pistia stratiotes and Eichornia crassipes plants when initially supplied with $300 \mu \mathrm{g} \mathrm{ml}^{-1}$ of $\mathrm{K}_{2} \mathrm{CrO}_{4}$ at $\mathrm{pH} 7$ and $37^{\circ} \mathrm{C}$ for 15 days of incubation period photosynthesized carbon into the rhizospheric environment. Root exudates primarily contain various organic acids, amino acids, sugars, proteins/enzymes, and other organic macromolecules which can stimulate soil microbial growth and activities in the rhizosphere by providing important substrates for microbial metabolism. Thus, concentrations of heterotrophic microorganisms in the rhizospheric soil can be over 4 to 100 -fold greater than the microbial concentrations in the bulk soil (Donnelly et al. 1994; Siciliano et al. 2003). This is a new report of the $\mathrm{Cr}(\mathrm{VI})$ reduction/removal using hydrophytes (Pistia stratiotes and Eichornia crassipes) along with Exiguobacterium-S8.

\section{Conclusion}

These results suggest that the capacity of Pistia stratiotes and Eichornia crassipes to remove $\mathrm{Cr}(\mathrm{VI})$ from solution 
was accelerated in the presence of bacterial strains (Bacillus pumilus-S4, Pseudomonas doudoroffi-S5 and Exiguobacterium-S8). This is because the plants release root exudates which help the bacteria strains. In turn, the bacterial strains release phytohormones which support the growth of hydrophytes growth. Many investigators also used Bacillus and Pseudomonas for the removal of heavy metals in the presence of different hydrophytes but chromate removal by Pistia stratiotes and Eichornia crassipes in the presence of Exiguobacterium is a new report for wastewater treatment. From these findings, it is easy to construct a wastewater bioreactor to treat chromium-polluted industrial wastewater.

Acknowledgments Higher Education Commission, Pakistan, is greatly acknowledge for the financial support under Grant No. 8-1/SIRSI/HEC for this work

\section{References}

Abou-Shanab RA, Delorme TA, Angle JS, Chaney RL, Ghanem K, Moawad H, Ghozlan HA (2003) Phenotypic characterization of microbes in the rhizosphere of Alyssum murale. Int. J. Phytoremediat 5:367-379

Becerra-Castro C, Monterroso C, Garcia-Leston M, Prieto-Fernandez A, Acea MJ, Kidd PS (2009) Rhizosphere microbial densities and trace metal tolerance of the nickel hyperaccumulator Alyssum serpyllifolium Subsp. Lusitanicum. Int. J. Phytoremediat 11:525-541

Bhowmick DC, Bal B, Chatterjee NS, Ghosh AN, Pal S (2009) A low-GC Gram-positive Thermoanaerobacter-like bacterium isolated from an Indian hot spring contains $\mathrm{Cr}(\mathrm{VI})$ reduction activity both in the membrane and cytoplasm. J Appl Microbiol 106:2006-2016

Camargo FA, Okeke BC, Bento FM, Frankenberger WT (2003) In vitro reduction of hexavalent chromium by a cell free extracts of Bacillus sp, ES 29 stimulated by $\mathrm{Cu}(2+)$. Appl Microbiol Biotechnol 62:569-573

Clesceri SI, Greenberg A, Eaton AD (1998) Standard methods for the examination of water and wastewater, 20th edn. American Public Health Association, Washington, D.C.

Danh LT, Truong P, Mammucari R, Tran T, Foster N (2009) Vetiver grass, Vetiveria zizanioides: a choice plant for phytoremediation of heavy metals and organic wastes. Int $\mathbf{J}$ Phytoremediat 11:664-691

Deleo PC, Ehrlich HL (1994) Reduction of hexavalent chromium by Pseudomonas fluorescens LB 300 in batch and continuous cultures. Appl Microbiol Biotechnol 40:756-759

Dhal B, Thatoi H, Das N, Pandey BD (2010) Reduction of hexavalent chromium by Bacillus sp. isolated from chromite mine soils and characterization of reduced product. J Chem Technol Biotechnol 85:1471-1479

Donnelly PK, Hegde RS, Fletcher JS (1994) Growth of PCBdegrading bacteria on compounds from photosynthetic plants. Chemosphere 28:981-988

Fathizadeh M, Fakhraee H, Aroujalian A (2011) Decontamination of hexavalent chromium and tri-ethyl phosphate stimulants through photocatalytic oxidation. Int J Environ Sci Technol $8: 863-871$

Gerhardt P, Murry RGE, Wood WA, Kreig NR (1994) Methods for general and molecular bacteriology. American Society for Microbiology, Washington, D.C.

Hanc A, Barałkiewicz D, Piechalak A, Tomaszewska B, Wagner B, Bulska E (2009) An analysis of long-distance root to leaf transport of lead in Pisum sativum plants by laser ablation-ICPMS. Int J Environ An Ch 89:651-659

Hewitt EJ (1963) Minerals nutrition of plants in culture media. In: Steward FC (ed) Plant physiology. Academic Press, New York

Horton RN, Apel WA, Thompson VS, Sheridan PP (2006) Low temperature reduction of hexavalent chromium by a microbial enrichment consortium and a novel strain of Arthrobacter aurescens. BMC Microbiol 6:5

Iqbal J, Rafique N (1987) Toxic effects of $\mathrm{BaCl}_{2}$ on germination, early seedling growth, soluble proteins and acid phosphatase in Zea mays L. Pak J Bot 19:1-8

Kerger B, Butler W, Paustenbach D, Zhang JD, Li SK (2009) Cancer mortality in Chinese populations surrounding an alloy plant with chromium smelting operations. J Toxicol Environ Health A 72:329-344

Komori K, Rivas A, Toda K, Ohtake H (1990) A method for removal of toxic chromium using dialysis-sac cultures of a chromatereducing strain of Enterobacter cloacae. Appl Microbiol Biotechnol 33:117-119

Li T, Yang X, Lu L, Islam E, He Z (2009) Effects of zinc and cadmium interactions on root morphology and metal translocation in a hyperaccumulating species under hydroponic conditions. J Hazard Mater 169:734-741

Mahadevan A (1984) Growth regulators, microorganisms and diseased plants. Oxford and IBH Publishing, India 31

Mnif S, Chamkha M, Sayadi S (2009) Isolation and characterization of Halomonas sp. strain C2SS100, a hydrocarbon-degrading bacterium under hypersaline conditions. J Appl Microbiol 107:785-794

Parmar P, Pillai A, Gupta V (2010) An improved colorimetric determination of micro amounts of chromium(VI) and chromium(III) using p-aminoacetophenone and phloroglucinol in different samples. J Anal Chem 65:582-587

Rand MC, Arnod E, Michel J, (1979) Standard methods for the examination of water and wastewater. American Public Health Association, Washington, D.C.

Rehman Y, Rizwan M, Faisal M, Hasnain S (2011) Seasonal effects of domestic wastewaters on the $\mathrm{Cr}(\mathrm{VI})$ reduction potential of Bacillus cereus S-6 and Ochrobactrum intermedium CrT-1. Biol. Environ. 110B:33-40

Siciliano SD, Germida JJ, Banks K, Greer CW (2003) Changes in microbial community composition and function during a polyaromatic hydrocarbon phytoremediation field trial. Appl Environ Microbiol 69:483-489

Soleimani M, Hajabbasi MA, Afyuni M, Mirlohi A, Borggaard OK, Holm PE (2010) Effect of endophytic fungi on cadmium tolerance and bioaccumulation by Festuca arundinacea and Festuca pratensis. Int J Phytoremediat 12:535-549

Sparks DL (1996) Methods of soil analysis. Part 3. Book Series, No. 5. Soil Science Society of America, Madison

Steel RGD, Torrie JH (1981) A biometrical approach. In: Principles and procedures of statistics, 2nd edn. McGraw Hill International Book Company, New York

Swarnalatha S, Ganesh KA, Tandaiah S, Sekaran G (2009) Efficient and safe disposal of chrome shavings discharged from leather 
industry using thermal combustion. J Chem Technol Biotechnol $84: 751-760$

Tarcan G, Akinci G, Danişman M (2010) Assessment of the pollution from tannery effluents upon waters and soils in and around Kula vicinity, Turkey. Water Air Soil Pollut 213:199-210
Wang YT, Xiao C (1995) Factor's affecting hexavalent chromium reduction in pure cultures of bacteria. Water Res 29:24672474 